\title{
Effect of Taxation and Fiscal Arrangement on Marginal Oil Field Investment Climate: A Theoretical Framework
}

\author{
Nor Aziah Abd Manaf ${ }^{1}$, Abdulsalam Mas'ud $^{1,2}$, Natrah Saad ${ }^{1}$ and Zuaini Ishak ${ }^{1}$ \\ ${ }^{1}$ School of Accountancy, College of Business, Universiti Utara Malaysia, Malaysia \\ ${ }^{2}$ Hussaini Adamu Federal Polytechnic, Kazaure, Jigawa State, Nigeria \\ Correspondence: Abdulsalam Mas'ud, School of Accountancy, College of Business, Universiti Utara Malaysia, \\ Sintok, Kedah, Malaysia. Tel: 60-16-683-9225; 234-703-682-4625. E-mail: masudabdussalam@gmail.com
}

\author{
Received: May 4, 2014 Accepted: June 13, 2014 Online Published: July 11, 2014 \\ doi:10.5539/ass.v10n15p89 \\ URL: http://dx.doi.org/10.5539/ass.v10n15p89
}

\begin{abstract}
The paper presents a theoretical framework on the moderating effect of attractive fiscal regime on taxation and fiscal arrangement on the investment climate of marginal oil fields in Malaysia. The variables proposed under examination are type of revenue-based tax, type of fiscal arrangement, production-based taxes, crypto-based taxes, and tax incentives. If validated, the model would have important policy implications to the host oil and gas producing countries and to marginal oil fields operators for investment decisions.
\end{abstract}

Keywords: investment climate, fiscal arrangement, fiscal regime, incentives, taxes

\section{Introduction}

This paper presents a theoretical framework on the influence of taxation and fiscal arrangement on the investment climate of marginal oil fields in Malaysia with the moderating role of attractive fiscal regime. Marginal oil field is defined as oil or gas reservoir not worth developing at a given time due to low revenue accruing from its operation. However, changing economic and technical conditions can render such a field commercially viable (Svalheim, 2004). While the above definition is generalized, many countries have their marginal oil field definitions. In the Netherlands, oil field is defined based on reserve levels; a gas field is classified as marginal when it holds less than four thousand million cubic meters of reserves, whereas in the United Kingdom marginal oil field is classified as a field with equivalent of 20 million barrels of oil (Akhigbe, 2007). Similarly, in Malaysia marginal oil field is defined as fields with average reserve of 30 million barrels of oil equivalent (Faizli, 2012; Na, Zawawi, Liew, \& Razak, 2012; Wei, 2011). In Texas and Indonesia marginal oil field is defined in terms of oil and gas production; the levels are 10 barrels per day in Texas and 10,000 barrels per day in Indonesia (Akhigbe, 2007). In Nigeria, the definition of marginal oil fields covers many spectrum such as fiscal terms, reserve level, production level and other conditions (Akhigbe, 2007).

Despite the many definitions, four parameters are key. These are fiscal terms (taxation and fiscal arrangement), reserve levels, production levels, and other economic conditions. However, the main focus of this paper is the effect of taxation and fiscal arrangement on marginal oil field investment climate. There are reasons for considering this dimension. Firstly, other factors that influence the investment climate of marginal oil fields which include reserve, production and economic conditions (e.g., oil and gas price) relate to some disciplines like mining, geology and economics. Secondly, the definition suggests that change in taxation and fiscal arrangement can cause change in the investment climate of marginal oil fields. Finally, studies on such effect are very scanty particularly in Malaysia.

\section{Marginal Oil Field Investment Climate}

Investment climate for the development of oil and gas resources is determined by the country's intrinsic and extrinsic indicators. Intrinsically, investment climate is determined by two factors: the rate of return which the country offers to investors and associated risk relating to the investment (Otto et al., 2006). However, extrinsically, investment climate is determined by geological potential, political stability, level of corruption, fiscal regime (taxation and fiscal arrangement), and government regulation (Dollar, Hallward-Driemeier, \& Mengistae, 2006; Dollar, Hallward-Driemeier, \& Mengistae, 2005; Hallward-Driemeier, Wallsten, \& Xu, 2006; 
Otto, et al., 2006). In line with the marginal oil field and investment climate definitions, taxation and fiscal arrangement are important exogenous indicators of a marginal oil field investment.

Evidence shows a continuous decline in oil and gas production in Malaysia due to stranded marginal oil fields (Malaysia Petroleum Resources Corporation, 2014). Developing such marginal oil fields in an economically attractive manner is also highly challenging (Na, et al., 2012). Thus, new tax incentives were introduced in 2010 to attract investment into such fields and fiscal arrangement was changed from Production Sharing Contract (PSC) to Risk Service Contract (RSC) in 2013 (Malaysia Petroleum Resources Corporation, 2014). However, despite these efforts, between 2010 and 2013 only three RSCs were signed for marginal oil fields compared to 17 PSCs for larger oil fields within almost the same period (Lee, 2013; Ley, 2012). Low acceleration in grasping the marginal oil fields compared to larger fields raises the question on the investment climate. Thus, the need to investigate to what extent taxation and fiscal arrangement affect marginal oil fields investment climate in Malaysia.

Moreover, comparison of Malaysia fiscal terms with that of other countries shows that its fiscal regime is relatively less attractive to investors. An analysis of global petroleum fiscal regimes between 1998 and 2007 found that Malaysia is among the countries with a rigid fiscal regime in terms of Government Take (GT), though in recent times it has been leveraging downward by reducing the GT and increasing the Contractor Take (CT) (Johnston, 2008). In rating six countries' fiscal regime (Portugal, Louisiana, Thailand, Nigeria, Malaysia, and Indonesia) in terms of GT for onshore and offshore operations, Khelil (1995) found that Malaysia was rated the second highest after Indonesia. High GT imply low CT, which can affect the investors' evaluation of the fields' investment climate. In comparing the fiscal regimes in Brunei, Indonesia, Malaysia, Thailand and Vietnam PSCs, Putrohari, Kasyanto, Suryanto, and Rashid (2007) revealed that Thailand royalty/tax concession of 1972 had the highest value in terms of investment, which was followed by Indonesian FTP of 1988. This also indicates low investment viability of Malaysia oil and gas fields.

While Malaysia has a relatively rigid fiscal regime that can affect the investment climate of its oil and gas fields, studies pay little attention on the influence of taxation and fiscal arrangement. Thus, this paper proposes a theoretical framework that attempts to explain the effect of taxation and fiscal arrangement on marginal oil field investment climate and the potential moderating role of attractive fiscal regime. Toward this end, the following fiscal terms will be investigated.

\section{Type of Revenue-based Tax}

Resource rent theory highlights that taxes create investment distortions (Árnason, 2008). Conversely, the more a tax targets pure economic rent, the less distortion it creates to investment(Árnason, 2008).This implies that different tax types have different investment distortions; thus, the most appropriate tax type is the one that creates the least (Nakhle, 2008). Nakhle (2008) disclosed three types of taxes that target pure economic rent: Brown Tax (BT), Resource Rent Tax, and Income Tax. Although each of these targets economic rent, comparison of advantages and disadvantages of these taxes shows that only BT targets investors' Net Cash Flow (NCF) and it is widely known that NCF is an important measure of investment attractiveness. More so, Freebairn and Quiggin (2010) concluded that BT had the desired efficiency and greater transparency in principle. Consequently, it can be argued that revenue tax type can have an effect on marginal oil field investment climate due to differential investment distortions, transparency and efficiency. Thus, the following proposition is developed.

\section{$\mathrm{P}_{1}$ : Type of revenue-based tax affects marginal oil field investment climate.}

\section{Type of Fiscal Arrangement}

Literature identifies three major fiscal arrangements, i.e., concessionary, production sharing, and service contracts, which are the most common agreements in the oil and gas industry. Even though each arrangement has its distinct attributes, in a few instances they share common features. Likosky (2009) posited that in countries where resource nationalism and anti-foreign sentiment are common, name attached to a particular form of arrangement may be more rhetorically important than the practice.

In the petroleum fiscal arrangement literature the different arrangements offer different levels of independence and resource control to a host country (Johnston, 1994, 2003). Likosky (2009) boldly argued that while the service contract gives a high level of independence to the host countries, production sharing arrangements are more desirable to attract developmental projects where exploration high risk exists. Thus, this indicates how different types of contractual arrangement can have varying implications to investors' evaluation of the field investment climate. 
Likosky (2009) further asserted that even within a particular country different projects require different contractual types. By implication, this shows that a particular form of fiscal arrangement can be made more desirable for marginal oil fields development project. Therefore, in line with the literature it can be argued that the type of fiscal arrangement can have an effect on the marginal oil field investment climate. Hence, the following proposition is developed.

\section{$\mathrm{P}_{2}$ Type of fiscal arrangement affects marginal oil field investment climate.}

\section{Production-based Taxes}

Production taxes are those forms of taxes paid by the investor based on mineral output regardless of whether economic rent (profit) is realized or not. These forms of taxes are less neutral than profit-based taxes as they do not target the economic profit directly but rather the overall revenue of the project (Menezes, 2005). Moreover, Phina (2005) argued that the absence of production-based taxes such as royalty positively influences the production of new/marginal oil field.

To reduce financial risks and improve field investment climate, companies generally prefer profit-based taxes instead of production-based taxes. This is because production-based taxes impose that companies make an upfront payment regardless of whether they recover their cost or not (McPhail, Daniel, King, Moran, \& Otto, 2009). McPhail et al. further asserted that production-based taxes are disliked for some reasons. They can have a negative effect on economic cut-off rates because they are regressive, and they are paid even in loss-making years (McPhail, et al., 2009). Based on these two reasons outlined by McPhail et al. (2009), it can be argued that production-based taxes can have an effect on marginal oil field investment climate due to their regressive nature and upfront payment even in the period of losses. Hence, the following proposition is formulated.

\section{$\mathrm{P}_{3}$ Production-based taxes affect marginal oil field investment climate.}

\section{Crypto-based Taxes}

Crypto-based taxes otherwise known as quasi-taxes or presence-based taxes are additional impositions made on the oil and companies based on their presence, and sometimes made regardless of whether production, revenue and/or profits are realized. According to Johnston (2003), crypto taxes are payment obligations by an investor company to a host country, but they do not appear in the GT calculation and are not recoverable either. Johnston (2003) further posited that they are price of doing business, and they vary among countries from the lowest to the highest. Examples of crypto taxes are domestic market obligation, security fees, custom duties, hostile audits, unclear regulations government participation, and hiring requirements (Abdulkarim, 2009).

It was also asserted that some crypto taxes that are not related to either a company output or profit are the most non-neutral among all categories of taxes as they place a tax liability on the companies even in the absence of production and/or revenue from oil and gas operation (Menezes, 2005). McPhail et al., (2009) opined that quasi taxes such as level of government participation, environmental obligation, technology transfer, skill training and employment have consequences for investment decisions and production efficiency.

However, statistical evidence on the effect of crypto taxes is nonexistent in the petroleum fiscal regime literature. In particular, mineral taxation literature has not explored the effect of crypto-based taxes on investment decision of companies theoretically or empirically(McPhail, et al., 2009). But, it can be argued that crypto taxes can have an effect on the investment climate of marginal oil fields as they increase the investors' obligation beyond those within the fiscal arrangement. As a result, the following proposition is developed.

\section{$\mathrm{P}_{4}$ Crypto-based taxes affect marginal oil field investment climate.}

\section{Tax Incentives}

Studies documented that, all things being equal, the effect of tax incentives on investment attractiveness were positive (Babatunde, 2012; Clark, 1999; Lim, 2001). However, other studies showed that incentives had no effect on attracting investment in less developed countries(Lim, 1983; Ricupero, 2000), and that it was difficult to evaluate its aggregate effect (Ricupero, 2000). Despite conflicting findings, evidence shows that investors have different preference to incentives. For instance, a survey of managers of US firms by Rolfe, Ricks, Pointer and McCarthy (1993) showed that new companies preferred incentives that can shrink their take-up expenses such as equipment acquisition cost while existing firms preferred incentives that target profits improvement. The former may mean investment incentive while the latter can be performance incentive. In the aggregate, Coyne (1994) suggested that small firms are more responsive to incentives than big ones. This implies that the marginal oil fields which are mostly dominated by small firms would be more responsive to incentives than larger fields; this justifies the investigation on the effect of tax incentives on their investment climate. 
Though empirical evidence on the effect of incentives on the investment climate in other industries exists, little evidence is available on the effect of tax incentives on marginal oil field investment climate. But the impact of incentives on the investment climate is evident in the oil and gas industry through simulation analysis (Kazikhanova, 2012; Kemp \& Stephen, 2011a, 2011b, 2012a, 2012b). Moreover, incentives on petroleum operation can be multidimensional; in their application, some incentives target incremental investment while others are intended to encourage productivity and performance.

Shimutwikeni (2011) opined that tax allowance is an important aspect in investment evaluation that can improve or destroy the competitiveness of a country's fiscal regime. Twinamatsiko (2009) highlighted the incentives that have the potential in increasing investors' appetite to Capital Expenditure (CAPEX) in Uganda's frontier oil and gas industry. He pointed that uplifts encourage capital investment as they reduce the tax liability of the investors, while tax holiday which requires the investors not to pay taxes during a certain period of time encourage investment in marginal oil fields. The author further contended that reinvestment allowance encourages the investors to reinvest their profit in a certain sector of the economy. In his study, McPhail et al. (2009) asserted that the introduction of new tax incentives increased exploration activity in some oil producing zones as new exploration license had been acquired, and progress was made in a number of mining projects. These incentives can be seen as targeting incremental investments.

One of the provisions of the Nigeria Memorandum of Understanding (MoU) with Foreign Oil Companies (FOCs) is an incentive intended to fire the interest of the companies to increase their performance in onshore and offshore deepwater (Onyeukwu, 2008). The Nigerian MoU is also expected to provide incentives in the form of bonuses meant for reserves additions (Kyari, 2013). In some US states incentives provided are meant to encourage companies' performance. For instance, tax reduction for deeper drilling, tax reduction during fall in oil price to encourage continued operations, and allowance for companies experiencing depletion aimed at maintaining the production from such fields, are likely to encourage companies' performance in different situations (Butcher, 2012). Consequently, these incentives can be seen as a means to improve performance.

Although tax incentive in oil and gas industry is multidimensional, there is limited evidence to validate this claim. So,a study needs to explore the effect of the different dimensions of tax incentives on marginal oil field investment climate. Hence, the following propositions are made.

$\mathrm{P}_{5}$ Tax incentive is multidimensional.

$\mathrm{P}_{6}$ Dimensions of tax incentive have an effect on marginal oil field investment climate.

\section{Attractive Fiscal Regime}

An attractive fiscal regime possesses certain features such as neutrality, stability, equity, flexibility, risk sharing, profit sharing, certainty, predictability, efficiency, clarity, simplicity, progressivity, adaptability, revenue raising potentials and transparency (Amoako-Tuffour \& Owusu-Ayim, 2010; Mohammed, 2012; Ogunlade, 2010; Sarsenbayev, 2010; Shimutwikeni, 2011; Treasure, 2012). Changes in oil price and competition in attracting extractive industries to invest can influence various oil exporting countries to offer attractive fiscal deals (Vivoda, 2011). Thus, an attractive fiscal regime that possesses the aforementioned attributes can stimulate the perceived adverse effect of production-based taxes on marginal oil field investment climate. A fiscal regime can be attractive when it consists of some neutral tax instruments, is stable and simple to administer (Akhigbe, 2007; Ogunlade, 2010; Oldianosen, 2004; Sarsenbayev, 2010). Moreover, Artist (2009) proposed that the effect of tax policy on private investor cash-flow can be moderated by a fiscal regime in place. This suggests that an attractive fiscal regime can have a stimulating effect on the influence of production-based tax on the marginal oil field investment climate; hence, the following proposition is offered.

$\mathrm{P}_{7}$ Attractive fiscal regime moderates the effect of production-based taxes on marginal oil fields' investment climate.

Nevertheless, the effect of crypto-based taxes on the marginal oil field investment climate may be contingent on the moderating influence of an attractive fiscal regime. The expectation is that the existence of the attractive fiscal regime can stimulate any adverse effect which crypto-based taxes may have on the marginal oil field investment climate because the fiscal regime is stable, neutral and simple. In other words, a fiscal regime that is stable, simple and contains neutral elements is expected to kindle the perceived adverse effect of crypto taxes on the marginal oil field investment climate. In fact, Artist (2009) proposed that the effect of country's tax policy on the investors' cash-flow can be moderated by a fiscal regime in place. This suggests that the existence of an attractive fiscal regime can stimulate the adverse effects that crypto-based taxes can have on the marginal oil field investment climate; hence, this proposition is made. 


\section{$\mathrm{P}_{8}$ Attractive fiscal regime moderates the effect of crypto-based taxes on marginal oil fields' investment climate.}

Although we argue for a significant effect of tax incentive on marginal oil field investment climate, global literature on the effect of incentive on investment attractiveness documents mixed findings (Tung \& Cho, 2000). In a literature survey, Morisset et al. (2000) reported that incentives generally neither caused serious negative effects on investment environment nor attracted the desired externalities. But despite inconsistencies in the literature and cautions by scholars on the use of incentives, states are likely to continue offering them (Buss, 2001). However, it is recommended that stability and simplicity of the fiscal regime would be more desirable to investors in an environment with political and institutional risks than generous tax rebates and incentives (Morisset, Pirnia, Allen, \& Wells, 2000).

Due to inconsistencies on the effect of incentives on investment attractiveness and viability and the relevance of attractive fiscal regime in attracting investment and enhancing project viability, it is proposed that an attractive fiscal regime can stimulate the relationship between tax incentives and marginal oil fields' investment climate. In fact, Baron and Kenny (1986) suggest the use of a moderator variable where there is inconsistency in findings.

Furthermore, the role of an attractive fiscal regime in stimulating the investment climate is relevant by invoking Moran's (1974) dynamic bargaining theory. The theory explains how host developing countries move up in a negotiation learning curve with increasing operating and supervisory skills. The power of negotiation of a multinational company eventually shifts in favor of host oil and gas producing countries (Vivoda, 2011). As host countries have more bargaining influence due to increased negotiation skills and consequently their bargaining power, it is implied that they have the power to pass or enforce laws relating to economic rent sharing (Nebus \& Rufin, 2010). Thus, when host countries can pass and enforce laws, it also means that they can design an attractive fiscal regime. With an attractive regime in place, multinational oil companies can evaluate the investment climate of marginal oil field development project. Therefore, it can be deduced from bargaining theory that as developing host countries gain more bargaining experience, an attractive fiscal regime capable of inducing FOCs to invest in the country's oil and gas fields can be developed. In this manner, a regime can outweigh the effect of non-neutral tax instruments and improve the benefit derived from FOCs in relation to tax incentives and allowances. Following the above, the following proposition is formulated.

$\mathrm{P}_{9}$ Attractive fiscal regime moderates the effect of tax incentive dimensions on marginal oil fields' investment climate.

\section{Proposed Theoretical Framework}

In line with the literature discussed above, Figure 1shows the proposed theoretical framework which depicts the direction of the relationship between the exogenous and endogenous variables. Perceptions of relevant stakeholders from industry, government and practitioners on the exogenous and endogenous variables will be solicited.

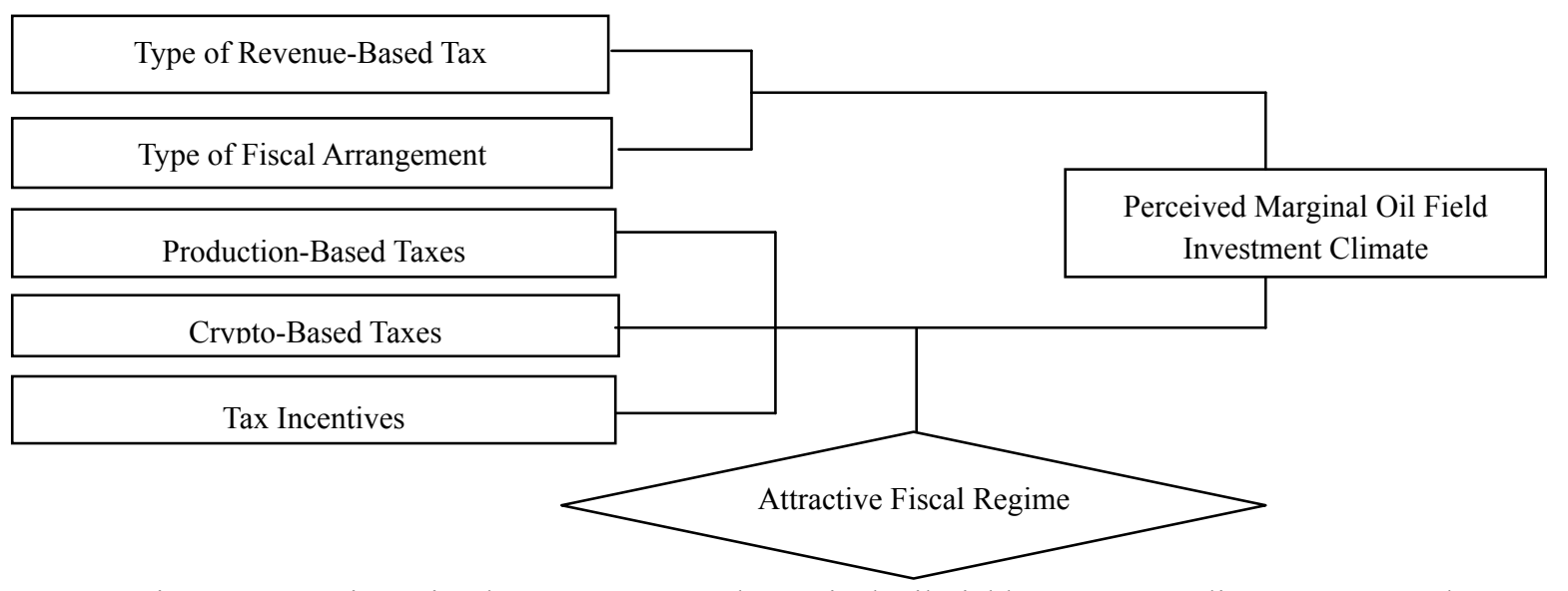

Figure 1. Taxation, Fiscal Arrangement and Marginal Oil Field Investment Climate Framework

\section{Conclusion}

The paper discusses the effect of taxation and fiscal arrangement on marginal oil field investment climate with attractive fiscal regime as a proposed moderator, as depicted in Figure 1. When the model is validated empirically, some policy insights can be offered to the Malaysian government, host oil producing countries, investors and academia. With continued decline in oil and gas production, the Malaysian government can devise 
relevant strategies to improve the investment climate in marginal oil fields. In fact it has been stressed by Islam, Jameel, Jumaat, Shirazi and Salman (2012) that exploring strategies that can improve oil and gas production in Malaysia is currently needed. Host oil producing countries with marginal oil reservoirs will also benefit from the proposed framework if validated as it may provide insights for them to develop an appropriate fiscal instruments that enhances the marginal oil field investment climate. The academia will also benefit from the study as it will provide additional evidence from a country with significant numbers of marginal oil fields. It will also benefit from a survey methodology because most of the previous studies used a scenario analysis. In fact Smith (2012) and Smith (2013) recommended the exploration of different methodologies relating to the effect of petroleum fiscal regime on investment. Finally, the framework when validated will also benefit investors of marginal oil fields by highlighting the fiscal terms which they can still bargain in optimizing their expected rate of return and reducing their potential investment risks.

\section{Acknowledgements}

We would like to thank Universiti Utara Malaysia for the FRGS Research Grant No. 12930. One of the authors also wishes to acknowledge his $\mathrm{PhD}$ scholarship to Universiti Utara Malaysia by the Nigerian Tertiary Education Trust Fund (TETFUND).

\section{References}

Abdulkarim, R. (2009). The Fiscal Tools in the UK Petroleum Licensing, How Did the UK Attract Investments and What Are the Effects of Changing Terms? CEPMLP Annual Review, 12.

Akhigbe, I. J. O. (2007). How Attractive is the Nigerian Fiscal Regime, Which is Intended to Promote Investment in Marginal Field Development? CAR CEPMLP Annual Review, 10.

Amoako-Tuffour, J., \& Owusu-Ayim, J. (2010). An Evaluation of Ghana's Petroleum Fiscal Regime. Ghana Policy Journal, 4, 7-34.

Árnason, R. (2008). Natural resource rents: Theoretical clarification. (Working Paper Series W08:07 ).

Artist, R. (2009). Optimizing Mining Taxation for the Mineral Industry in Suriname: A Case Study of the Bauxite Mining Sector. MBA, Maastricht School of Management (MSM), The Netherland.

Babatunde, S. A. (2012). The Impact of Tax Incentives on Foreign Direct Investment in the Oil and Gas Sector in Nigeria. Journal of Business and Management, 6(1), 1-15.

Baron, R. M., \& Kenny, D. A. (1986). The Moderator-Mediator Variable Distinction in Social Psychological Research: Conceptual, Strategic, and Statistical Considerations. Journal of Personality and Social Psychology 51(6), 1173-1182.

Buss, T. F. (2001). The effect of state tax incentives on economic growth and firm location decisions: An overview of the literature. Economic Development Quarterly, 15(1), 90-105.

Butcher, B. D. (2012). Alaska's Oil and Gas Fiscal Regime: A Closer Look from a Global Perspective. Alaska: Alaska Department of Revenue.

Clark, B. (1999). Using Tax Incentives to Encourage Investment in the Australian Film Industry. Revenue Law Journal, 9(1), 4.

Coyne, E. (1994). An articulated analysis model for FDI attraction into developing countries. MBA thesis. Nova Southeastern University, Fort Lauderdale, Fla.

Dollar, D., Hallward-Driemeier, M., \& Mengistae, T. (2006). Investment climate and international integration. World Development, 34(9), 1498-1516.

Dollar, D., Hallward - Driemeier, M., \& Mengistae, T. (2005). Investment climate and firm performance in developing economies. Economic Development and Cultural Change, 54(1), 1-31.

Faizli, A. A. (2012). Is Malaysia's Rigid Fiscal Regime the Best Recipe for Petronas' Success?. The Malaysian Insider. Retrieved from http://www.themalaysianinsider.com/sideviews/article/is-malaysias-rigid-fiscalregime-the-best-recipe-for-petronas-success-anas-alam-faizli/

Freebairn, J., \& Quiggin, J. (2010). Special Taxation of the Mining Industry. Economic Papers: A journal of applied economics and policy, 29(4), 384-396.

Hallward - Driemeier, M., Wallsten, S., \& Xu, L. C. (2006). Ownership, investment climate and firm performance. Economics of Transition, 14(4), 629-647.

Islam, A., Jameel, M., Jumaat, M. Z., Shirazi, S., \& Salman, F. A. (2012). Review of offshore energy in Malaysia 
and floating Spar platform for sustainable exploration. Renewable and Sustainable Energy Reviews, 16(8), 6268-6284.

Johnston, D. (1994). Global petroleum fiscal systems compared by contractor take. Oil and Gas Journal (United States), 92(50).

Johnston, D. (2003). International exploration economics, risk and contracts analysis. PennWell Books.

Johnston, D. (2008). Changing fiscal landscape. The Journal of World Energy Law \& Business, 1(1), 31-54.

Kazikhanova, A. (2012). Investment Climate in the UKCS after the Budget 2011 Changes. Msc, University of Aberdeen, Aberdeen.

Kemp, A. G., \& Stephen, L. (2011a). The effects of Budget 2011 on Activity in the UK Continental Shelf. Aberdeen Centre for Research in Energy Economics and Finance, North Sea Study Occasional Paper No. 123.

Kemp, A. G., \& Stephen, L. (2011b). The Short and Long Term Prospects for Activity in the UK Continental Shelf: the 2011 Perspective. Aberdeen Centre for Research in Energy Economics and Finance, North Sea Study Occasional Paper No. 122.

Kemp, A. G., \& Stephen, L. (2012a). A Comparative Study of Tax Reliefs for New Developments in the UK Continental Shelf after Budget 2012. Aberdeen Centre for Research in Energy Economics and Finance, North Sea Study Occasional Paper No. 124.

Kemp, A. G., \& Stephen, L. (2012b). Prospects for Activity in the UK Continental Shelf after Recent Tax Changes: the 2012 Perspective. Aberdeen Centre for Research in Energy Economics and Finance, North Sea Study Occasional Paper No. 125.

Khelil, C. (1995). Fiscal Systems for Oil: The Government "Take" and Competition for Exploration Investment. Public Policy for the Private Sector, 46(May).

Kyari, A. K. (2013). A theoretical and empirical investigation into the design and implementation of an appropriate tax regime: An evaluation of Nigeria's petroleum taxation arrangements. PhD Thesis, Robert Gordon University, UK, Aberdeen. Retrieved from http://openair.rgu.ac.uk

Lee, E. T. H. (2013). Scope For Improvement: Malaysia's Oil And Gas Sector. Retrieved from http://refsa.org/wp/wp-content/uploads/2013/07/OG-Scoping-Report-Malaysia-final-20130701.pdf

Ley, L. N. (2012). Member Country Report of Malaysia 48th CCOP Annual Session (Part 1) 5-8 November 2012. Langkawi, Malaysia: Coordinating Committee for Geoscience Programmes in East and Southeast Asia.

Likosky, M. (2009). Contracting and regulatory issues in the oil and gas and metallic minerals industries. Transnational Corporations, 18(1), 1.

Lim, D. (1983). Fiscal incentives and direct foreign investment in less developed countries. The Journal of Development Studies, 19(2), 207-212. http://dx.doi.org/10.1080/00220388308421859

Lim, E. -G. (2001). Determinants of and the relation between foreign direct investment and growth: A summary of the recent literature. International Monetary Fund.

Malaysia Petroleum Resources Corporation. (2014). History of Oil and Gas Industry in Malaysia-Petroleum Income Tax act 2010. Retrieved May 5, 2014, from http://www.mprc.gov.my/industry/history-ofoil-gas-in-malaysia

McPhail, K., Daniel, P., King, T. W., Moran, T. H., \& Otto, J. (2009). Minerals Taxation Regimes- A review of issues and challenges in their design and application. Mineral Taxation Regime: Analysis and Observation: Commonwealth Secretariat and International Council and Mines and Metal.

Menezes, R. (2005). Does India's Tax Regime for Minerals Achieve Its Objectives. CAR CEPMLP Annual Review, 9.

Mohammed, A. -N. (2012). Fiscal Regime Analysis: What Lessons Will Ghana Learn From Norway? CAR CEPMLP Annual Review, 16.

Moran, T. H. (1974). Multinational corporations and the politics of dependence: Copper in Chile. Princeton University Press Princeton, NJ.

Morisset, J., Pirnia, N., Allen, N., \& Wells, L. (2000). How tax policy and incentives affect foreign direct investment. Citeseer. 
Na, K., Zawawi, N. W. A., Liew, M., \& Razak, Z. A. (2012). Opportunities of Platform Reuse in Malaysia. Energy, 60, 70.

Nakhle, C. (2008). Petroleum taxation: sharing the oil wealth: A study of petroleum taxation yesterday, today and tomorrow. Psychology Press.

Nebus, J., \& Rufin, C. (2010). Extending the bargaining power model: Explaining bargaining outcomes among nations, MNEs, and NGOs. Journal of International Business Studies, 41(6), 996-1015. doi: $10.2307 / 40731693$

Ogunlade, A. (2010). How Can Government Best Achieve its Objectives for Petroleum Development: Taxation and Regulation or State Participation? CEPMLP, Dundee.

Oldianosen, E. (2004). How attractive are the fiscal regimes of the deepwater areas offshore west africa to foreign investment. Oil, Gás \& Energy Law Intelligence-OGEL, 2(3).

Onyeukwu, H. (2008). The Incentives in the Fiscal Framework of The Nigerian MoUs with the International Oil Companies: Have the Objectives Been Achieved? http://works.bepress.com/humphrey_onyeukwu/3

Otto, J., Andrews, C., Cawood, F., Doggert, M., Guj, P., Stermole, F., . . Tilton, J. (2006). Mining Royalties: A Global Study of Their Impact on Investors, Government and Civil Society: The World Bank.

Phina, A. O. (2005). Mineral and Petroleum Taxation: Are there Economic Limits to Efficient Taxation in Mineral and Petroleum Fiscal Regimes? CAR CEPMLP Annual Review, 8.

Putrohari, R. D., Kasyanto, A., Suryanto, H., \& Rashid, I. M. A. (2007). PSC Terms and Condition and Its Implementation in South East Asia Region. Proceedings og Indonesia Petroleum Association, 31st Annual Convention and Exhibition.

Ricupero, R. (2000). Tax Incentives and Foreign Direct Investment: A Global Survey ASIT Advisory Studies (Vol. 16). Geneva: United Nations Conference on Trade and Development.

Rolfe, R. J., Ricks, D. A., Pointer, M. M., \& McCarthy, M. (1993). Determinants of FDI incentive preferences of MNEs. Journal of International Business Studies, 335-355.

Sarsenbayev, K. (2010). Evaluation of Fiscal Regime for Subsoil Users in the Republic of Kazakhstan. CAR CEPMLP Annual Review, 13.

Shimutwikeni, N. S. (2011). What is a Competitive Fiscal Regime for Foreign Investment? With Special Reference to Namibia and Botswana. CAR CEPMLP Annual Review, 14.

Smith, J. L. (2012). Issues in Extractive Resource Taxation: A Review of Research Methods and Models. (WP/12/287). IMF Working Paper. Retrieved from http://papers.ssrn.com/sol3/papers.cfm?abstract id= $2202638 \&$ download $=$ yes

Smith, J. L. (2013). Issues in extractive resource taxation: A review of research methods and models. Resources Policy, 38(3), 320-331. http://dx.doi.org/10.1016/j.resourpol.2013.06.004

Svalheim, S. (2004). Marginal Field Development - a Norwegian Perspective. The 3rd PPM Seminar Chiang Mai, September 22nd 2004

Treasure, W. (2012). Fiscal Reform in Libya to Benefit From Non-Petroleum Mineral Potential - Considering The Australian Minerals Resource Rent Tax Model. CAR CEPMLP Annual Review, 16.

Tung, S., \& Cho, S. (2000). The impact of tax incentives on foreign direct investment in China. Journal of International Accounting, Auditing and Taxation, 9(2), 105-135.

Twinamatsiko, F. N. (2009). Is Uganda's Petroleum Fiscal Regime Sustainable? An Assessment. CAR CEPMLP Annual Review, 13.

Vivoda, V. (2011). Bargaining Model for the International Oil Industry. Business and Politics, 13(4), 1-34.

Wei, Q. H. (2011). Industry Focus: Oil \& Gas Companies. In W. M. Tek (Ed.), Malaysia Equity Research PP 11272/04/2012. Kuala Lumpur HWANGDBS Vickers Research Sdn Bhd.

\section{Copyrights}

Copyright for this article is retained by the author(s), with first publication rights granted to the journal.

This is an open-access article distributed under the terms and conditions of the Creative Commons Attribution license (http://creativecommons.org/licenses/by/3.0/). 